\title{
Dividend Policy and its Impact on Firms Financial Position
}

\author{
K. Phani Kumar ${ }^{1}$, K. Venkateswarlu ${ }^{2}$, Hye-jin $\mathrm{Kim}^{3}$ and Chen Haoyue ${ }^{4}$ \\ ${ }^{1,2}$ Department of Management Studies, VFSTR University, Vadlamudi, \\ Andhra Pradesh, India \\ ${ }^{3}$ Business Administration Research Institute, Sungshin Women's University, \\ 2, Bomun-ro 34da-gil, Seongbuk-gu, Seoul, Korea \\ ${ }^{4}$ Hangzhou Dianzi University, No.1158\# Baiyang Second Street, Hangzhou Economic \\ Development Zone, Hangzhou City, Zhejiang Province \\ 3hyejinaa@daum.net, ${ }^{3} 277879803 @ q q . c o m$
}

\begin{abstract}
The prime goal of budgetary administration in associations is to amplify its incentive to the proprietors and the investors. Even though this is tested by numerous specialists, the incentive here is frequently comprehended to be reflected in the organization's offer cost. As indicated by Barman if profits are the key marker of offer cost and afterward share cost is the key pointer of firm esteem, to augment investors riches, the organization ought to embrace a profit arrangement that will expand the offer cost. At the point when an organization makes benefits, it can either choose to hold the benefits for interests in new ventures or payout to the investors as profits. Profit strategy alludes to the arrangement of principles or standards that an organization takes after to choose the amount of its benefit it will pay out to investors. In any case, the decision of paying profits is eventually chosen by the top managerial staff of the organization, and once profits have been pronounced, it turns into an obligation to the firm and can't be toppled effectively.
\end{abstract}

Keywords: Investors, Organization, Profit strategy, Managerial staff

\section{Introduction}

There are different structures and routes in which profits can be paid; an organization may choose to pay profits as trade more than once out a year or announce extra offers. As indicated by Erasmus, from a financial specialist's point of view, it isn't just the level of profit installment that might be basic, yet additionally the security of profit installments for an impressive period. In this manner, the administration ought to be perceptive of the way that unexpected changes in profit installments could distance existing and potential financial specialists. Precarious profit arrangements may have an unfriendly speculators' view of the organization's execution in the money-related markets. This undertaking means to give a comprehension of the profit approach by surveying the current hypotheses on profit strategy and their exact discoveries. Besides, the paper looks at the exact examinations completed by researching the connection between profit strategy and firm an incentive as measured by its offer cost and friends execution. To look at the conceivable effect an association's profit approach may have on the money-related execution of various types of organizations. To see

Article history:

Received (December 29, 2013), Review Result (February 5, 2014), Accepted (April 5, 2014) 
whether there is any critical connection between profit strategy and a company's productivity. This examination essentially endeavors to analyze a portion of the highlights that decide the conduct of firms' profit payouts in India. The decision of the organizations' emerges because of the recurrence in which profits are paid to investors and the accessibility of possession structure information for the period under thought. Furthermore, the organization's fairly estimated worth will increment or decline while declaring profits.

\section{Dividend}

Dividend alludes to a reward, money, or something else, that an organization provides for its investors. Profits can be issued in different structures, for example, money installments, stocks, or some other frame. An organization's profit is chosen by its directorate, what's more, it requires the investors' endorsement. Be that as it may, it is not required for an organization to pay a profit. Profit is typically a piece of the benefit that the organization shares with its investors.

A profit is an installment made by an organization to its investors, for the most part as dissemination of benefits. At the point when a partnership gains a benefit or overflow, the organization can re-put the benefit in the business (called held income) and pay an extent of the benefit as a profit to investors. Conveyance to investors might be in real money (generally a store into a ledger) or, if the organization has a profit reinvestment design, the sum can be paid by the issue of further offers or, then again share repurchase.

A profit is distributed as a settled sum for each offer, with investors accepting a profit to the extent of their shareholding. For the business entity, paying profits is not a cost; rather, it is the division of after assessment benefits among investors. Held income (benefits that have not been appropriated as profits) are appeared in the investors' value segment on the organization's adjust sheet - the same as its issued share capital. Open organizations normally pay profits on a settled calendar, however may announce a profit whenever now and again called an extraordinary profit to recognize it from the settled calendar profits. Cooperatives, then again, apportion profits as per individuals' actions, so their profits are frequently thought to be a pre-impose cost.

\section{Payment forms}

1. Dividend of Cash

2. Dividend of Stock or Scrip

3. Dividend of Stock distribution

4. Dividend of Property

5. Dividend of Interim

6. Dividend of others

\subsection{Dividend of cash}

Cash profits are the most well-known type of installment and are paid out in money, more often than not using electronic assets exchange or a printed paper check. Such profits are a type of speculation pay and are typically assessable to the beneficiary in the year they are paid. This is the most widely recognized technique for sharing corporate benefits with the investors of the organization. For each offer claimed, a proclaimed measure of cash is circulated. Consequently, if a man claims 100 offers and the money profit is 50 pennies for 
each offer, the holder of the stock will be paid $\$ 50$. A profit paid does not appear on a pay articulation but rather appears on the monetary record.

\subsection{Dividend of stock or scrip}

Stock or scrip profits are those paid out as extra stock offers of the issuing organization, or another partnership, (for example, its backup organization). They are generally issued to the extent of shares claimed (for instance, for every 100 offers of stock possessed, a 5\% stock profit will yield 5 additional offers). Nothing unmistakable will be picked up if the stock is partly because the aggregate number of shares expands, bringing down the cost of each offer, without changing the market capitalization, or aggregate esteem, of the offers held.

\subsection{Dividend of stock distribution}

Stock profit disseminations are issues of new offers made to constrained accomplices by an association as extra offers. Nothing is part, these offers increment the market capitalization and aggregate estimation of the organization in the meantime diminishing the first cost premise per share. Stock profits are not includable in the gross salary of the investor for US salary imposes purposes. Since the offers are issued for continues equivalent to the previous showcase cost of the offers; there is no negative weakening in the sum recoverable.

\subsection{Dividend of property}

Property profits or profits in species (Latin for "in kind") are those paid out as resources from the issuing organization or another enterprise, for example, a backup organization. They are moderately uncommon and most oftentimes are securities of different organizations claimed by the backer, in any case, they can take different structures, such as items and administrations.

\subsection{Dividend of interim}

Between time profits are profit installments made before an organization's Annual General Meeting (AGM) and last budgetary articulations. This pronounced profit generally goes with the organizations between time money-related explanations.

\subsection{Dividend of others}

Different profits can be utilized as a part of an organized fund. Money-related resources with known showcase esteem can be dispersed as profits; warrants are once in a while conveyed along these lines. For vast organizations with backups, profits can appear as shares in an auxiliary organization. A typical strategy for "turning off" an organization from its parent is to appropriate offers in the new organization to the old organization's investors. The new offers would then be able to be exchanged freely.

\section{Dividend of reliability}

1. Payout ratio

2. Dividend cover

3. Dividend Cover Ratio 


\subsection{Dividend of dates}

1. Declaration date

2. In-dividend date

3. Ex-dividend date

4. Book closure date

5. Record date

6. Payment date

\subsection{Dripdividend reinvestment plan}

An arrangement offered by certain profit-paying enterprises that enables you to naturally reinvest money profits by buying extra offers of stock on the profit installment date.

\subsection{Yield of dividend}

A money-related proportion that shows how much an organization pays out in profits each year in respect to its share cost. It is computed by partitioning the yearly profit per share by the present cost of the stock.

\section{Dividend dates}

\subsection{Ex-dividend date}

The date on or after which stock is exchanged without a formerly proclaimed profit.

\subsection{One-time dividend}

An uncommon profit paid notwithstanding customary money profits.

\subsection{Installment date}

The date a proclaimed profit is booked to be paid. Investor Any individual, organization, or establishment that claims no less than one offer in an organization. Likewise called an investor.

\section{Policy of dividend}

The dividend policy is one of the most challenging topics of modern financial economics. It is a policy or guidelines a company uses to decide the number of dividends a company will pay to its shareholders when to pay and the intervals of payments.

Brealey, Myers, and Marcus define it as the decision of whether to pay out earnings as dividends or to reinvest them. Described dividend policy as the regulation and guidelines that a company uses to decide to make dividend payments to its shareholders.

Typically, older and more mature companies will tend to have a higher dividend payout as they have the financial capabilities to pay out more to shareholders. Also, some companies, especially new ones, will prefer to have a lower dividend payout ratio to retain earnings that can be utilized for future company growth. One argument to justify the payment of dividends 
is that dividends are cash in hand, while capital gains are cash in the bush. Capital gains to be received in the future should be riskier than the dividends received today.

\section{Financial performance}

Amidu and Abor (2006) described ways of measuring financial performance. These include; profitability, cash flow, sales growth, and market-to-book value. The portion of earnings not paid out to investors is ideally reinvested back to the company to provide for future earnings growth. Investors are very keen on finding out how much of the earnings is issued out to investors and how much is kept back to the company. Earnings kept from the investors are known as retained earnings, which ideally should be reinvested to provide for future earnings growth. They hope that the firms will use their retained earnings to either maximize their current operations or invest them to recoup higher profits. Financial performance is a subjective measure of how well a firm can use its assets from its primary mode of business to generate higher revenues. All organizations have financial performance measures as part of their performance management, although there is debate as to the relative importance of financial and non-financial indicators.

Financial performance can also be measured using Cash flow which is the difference between the amount of cash at the end of the period and the amount of cash at the beginning of the same period. Positive cash flows indicate a positive financial performance while a negative one indicates poor performance. Ross,

Westerfield and Jaffe (1999) define cash flow as cash generated by the firm and paid to creditors and shareholders. It can also be measured by the Balance sheet strength. This is the company's assets relative to its liabilities at a specific point in time. More assets and fewer liabilities result in a stronger balance sheet. A strong balance sheet is highly preferred. Several ratios can be calculated from the balance to measure financial performance

E.g.; return on Assets,

Return on Investments, Return on Equity, etc

\section{Relationship between dividends and firm performance}

Dividends are that part of the profits of a company that is distributed amongst its shareholders (Mohan raj\& Deepa, 2012). Since most of the firms pay cash dividends it then means that they have to decide on what percentage of their earnings they are going to distribute to their shareholders and this means coming up with a dividend policy to apply. According to Black (1976), the dividend policy has remained a great puzzle that many scholars have tried to solve. In coming up with a dividend policy a firm has to decide what share of its earnings is going to be distributed to its shareholders since shareholders are interested in the maximization of their wealth which they receive as dividends. The question is whether dividends do affect the performance of the firm in terms of the share price (Baker \& Powell, 1999).

\section{Factors influencing dividend policy of firms}

For a successful company, the income earned can either be used In acquiring additional assets, used to acquire securities, used to retire debt, or distributed to shareholders as dividends. There is a possibility of problems that can arise if a company decides to Distribute its income to shareholders which can Include the proportion to which the income Would be distributed to shareholders; whether this distribution should be in the form of cash dividends, 
or the cash be passed on to the shareholders by way of buying back some of their shares; and also how stable should the distribution of dividends be From the above many reasons are often cited as to why companies should pay or not pay dividends. Through previous empirical studies, several factors have been identified which influence the dividend payout ratios of firms which include the following: profitability, risk, cash flow, agency cost, and growth.

\section{Data analysis through graphical representation}

\section{Reliance communication}

1. Companies can issue final dividends only

2. The share prices increase after paying dividends

3. No of the trades are having a mixed combination

4. The dividends affect on buying of shares

Table 1. Data for reliance communication

\begin{tabular}{|l|l|l|l|l|}
\hline Date & $\begin{array}{l}\text { Open } \\
\text { Price }\end{array}$ & $\begin{array}{l}\text { High } \\
\text { Price }\end{array}$ & $\begin{array}{l}\text { Low } \\
\text { Price }\end{array}$ & $\begin{array}{l}\text { Close } \\
\text { Price }\end{array}$ \\
\hline $27 / 04 / 2006$ & 315 & 316.3 & 297 & 299.35 \\
\hline $28 / 04 / 2006$ & 291.25 & 309.2 & 279.35 & 300.65 \\
\hline $29 / 04 / 2016$ & 305 & 322 & 305 & 320 \\
\hline $2-$ Mar-07 & 425.15 & 431.9 & 410.25 & 415.3 \\
\hline $5-$ Mar-07 & 419.3 & 419.3 & 385.9 & 398.65 \\
\hline $6-$ Mar-07 & 403.75 & 414.4 & 394.1 & 400.95 \\
\hline $21 / 03 / 2008$ & 402 & 411.5 & 398.2 & 409.95 \\
\hline $22 / 03 / 2008$ & 413.05 & 428.15 & 413.05 & 426.35 \\
\hline $23 / 03 / 2008$ & 431 & 433.9 & 423.1 & 425.55 \\
\hline 7 -Oct-09 & 272 & 273.4 & 260.55 & 262.05 \\
\hline $8-$ Oct-09 & 265 & 268 & 244.8 & 246.3 \\
\hline $9-$ Oct-09 & 247.35 & 255.5 & 246.65 & 249.35 \\
\hline $26 / 04 / 2010$ & 168.1 & 170.75 & 168.1 & 168.65 \\
\hline $27 / 04 / 2010$ & 167 & 169.4 & 167 & 168.35 \\
\hline $28 / 04 / 2010$ & 166 & 170.35 & 165.05 & 165.55 \\
\hline $21 / 04 / 2011$ & 105.4 & 107.3 & 105.1 & 106.3 \\
\hline $22 / 04 / 2011$ & 106.5 & 106.85 & 104.3 & 104.8 \\
\hline $23 / 04 / 2011$ & 104.85 & 107.25 & 104.75 & 106.15 \\
\hline $20 / 04 / 2012$ & 85.7 & 87.85 & 85.2 & 86.25 \\
\hline $23 / 04 / 2012$ & 85.9 & 86.2 & 81.1 & 81.5 \\
\hline $24 / 04 / 2012$ & 82 & 82.1 & 78.7 & 80.4 \\
\hline $16 / 04 / 2013$ & 77.7 & 84.5 & 77.4 & 83.15 \\
\hline $17 / 04 / 2013$ & 84 & 85.3 & 81.15 & 82.1 \\
\hline $18 / 04 / 2013$ & 81.75 & 87.05 & 81.75 & 86.1 \\
\hline $21 / 04 / 2014$ & 131.1 & 134 & 131.1 & 133.65 \\
\hline $22 / 04 / 2014$ & 134.05 & 135.3 & 132.15 & 132.85 \\
\hline $23 / 04 / 2014$ & 133.2 & 134.6 & 131.3 & 132 \\
\hline $17 / 04 / 2015$ & 70.5 & 72.35 & 69.6 & 69.85 \\
\hline $20 / 04 / 2015$ & 70.15 & 70.55 & 65.5 & 66.05 \\
\hline $21 / 04 / 2015$ & 66.5 & 67.35 & 65.3 & 65.7 \\
\hline $8-$ Mar-16 & 55.05 & 55.85 & 53.75 & 54.55 \\
\hline $9-$ Mar-16 & 54.3 & 55.4 & 54.1 & 55.05 \\
\hline $10 / 3 / 2016$ & 55.5 & 55.65 & 53.35 & 53.8 \\
\hline & & & & \\
\hline
\end{tabular}




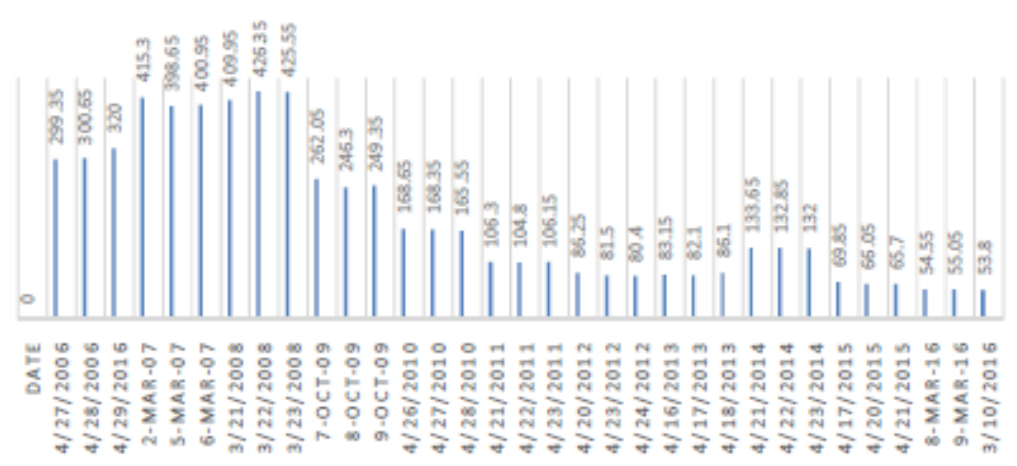

Figure 1. Graphical representation for reliance communication

\section{ITC COMPANY}

1. Companies can issue final dividends.

2. Share prices are also increasing.

3. Trades are having mixed combinations.

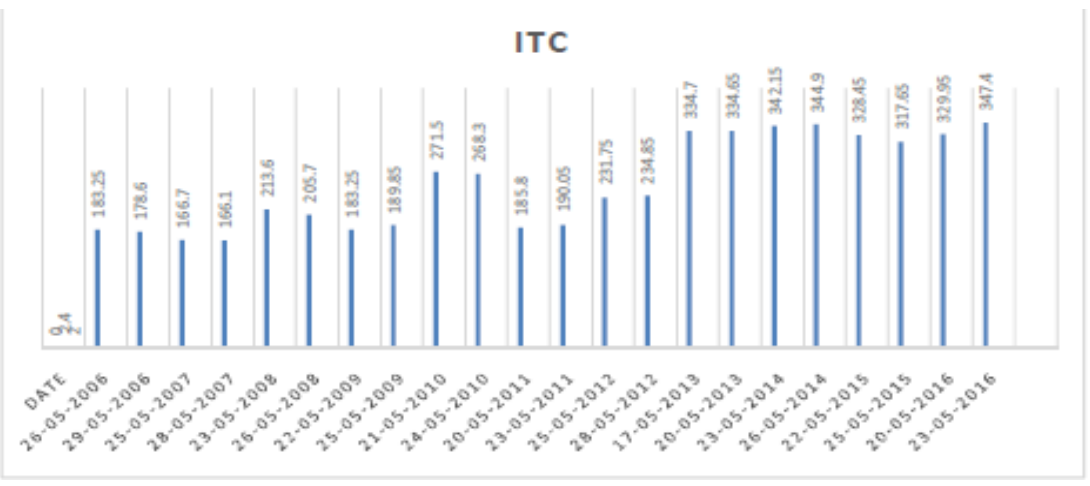

Figure 2. Graphical representation for ITC Company

\section{Conclusion}

The results of the capable check using return on an incentive as an execution measure are enduring with the delayed consequences of the examination using return on assets. This, therefore, shows the significance of the benefit game plan to the regard and execution of firms in India. Thusly, it is basic for those who depended on the issues of the firm to designate sufficient time and different assets in the outline and execution of a hearty profit strategy. Without a doubt, the discoveries of this examination may help arrangement producers on profit strategy choice. By and by, with the end goal of the research, it is likewise critical to extend the outskirts of this examination by picking a bigger example estimate with extra factors. At long last, factors, for example, proprietorship structure, board creation, and impact of duty on profit strategy may be a productive road for facilitating observational. Organizations may have a negative relationship that affects financial specialists' capacity to purchase offers There is no flawless positive or negative snapshot of the profit payouts it has 
a blended mix of both positive and negative. In some cases, profit influences share the cost, and now and again doesn't the organization's budgetary position affects the profits.

Table 2. Data for ITC company

\begin{tabular}{|l|l|l|l|l|}
\hline Date & $\begin{array}{l}\text { Open } \\
\text { Price }\end{array}$ & $\begin{array}{l}\text { High } \\
\text { Price }\end{array}$ & $\begin{array}{l}\text { Low } \\
\text { Price }\end{array}$ & $\begin{array}{l}\text { Close } \\
\text { Price }\end{array}$ \\
\hline $26 / 05 / 2006$ & 184 & 190.35 & 178.7 & 183.25 \\
\hline $29 / 05 / 2006$ & 185 & 185.95 & 176.7 & 178.6 \\
\hline $25 / 05 / 2007$ & 164 & 168.4 & 164 & 166.7 \\
\hline $28 / 05 / 2007$ & 167.85 & 169.95 & 165.1 & 166.1 \\
\hline $23 / 05 / 2008$ & 223.1 & 225.7 & 211.8 & 213.6 \\
\hline $26 / 05 / 2008$ & 209 & 211 & 201.65 & 205.7 \\
\hline $22 / 05 / 2009$ & 184.9 & 185.2 & 180.15 & 183.25 \\
\hline $25 / 05 / 2009$ & 186.3 & 190.6 & 182.6 & 189.85 \\
\hline $21 / 05 / 2010$ & 263 & 274.1 & 257.1 & 271.5 \\
\hline $24 / 05 / 2010$ & 273.5 & 281.95 & 266.6 & 268.3 \\
\hline $20 / 05 / 2011$ & 190 & 191.5 & 183.65 & 185.8 \\
\hline $23 / 05 / 2011$ & 187 & 190.5 & 186.35 & 190.05 \\
\hline $25 / 05 / 2012$ & 234.75 & 235.95 & 230.3 & 231.75 \\
\hline $28 / 05 / 2012$ & 233.5 & 235.85 & 232.45 & 234.85 \\
\hline $17 / 05 / 2013$ & 338 & 341.2 & 333.45 & 334.7 \\
\hline $20 / 05 / 2013$ & 335.5 & 342.2 & 334.05 & 334.65 \\
\hline $23 / 05 / 2014$ & 348.5 & 349.3 & 340.35 & 342.15 \\
\hline $26 / 05 / 2014$ & 345.2 & 347.5 & 340.5 & 344.9 \\
\hline $22 / 05 / 2015$ & 329.8 & 333.2 & 325.8 & 328.45 \\
\hline $25 / 05 / 2015$ & 322 & 324.4 & 317.25 & 317.65 \\
\hline $20 / 05 / 2016$ & 326.8 & 337.85 & 325 & 329.95 \\
\hline $23 / 05 / 2016$ & 347.1 & 354.75 & 339.75 & 347.4 \\
\hline
\end{tabular}

\section{References}

[1] WWW.BSE.COM.

[2] Monetary Control India.

[3] Research Articles on Dividend Policy.

[4] Journals in Library. 